\title{
Aquatic Biomass as a Source of Fuels and Chemicals
}

Lawrence P. Raymond

September 1983

Presented at

First U.S.-China Conference on

Energy, Resources, and Environment

Beijing, People's Republic of China

7-12 November 1982

Prepared under Task No. 1028.20

WPA No. 350

Solar Energy Research Institute

A Division of Midwest Research institute

1617 Cole Boulevard

Golden, Colorado 80401

Prepared for the

U.S. Department of Energy

Contract No. EG-77-C-01-4042 
Printed in the United States of America Available from:

National Technical Information Service

U.S. Department of Commerce

5285 Port Royal Road

Springfield, VA 22161

Price:

Microfiche A01

Printed Copy A02

\begin{abstract}
NOTICE
This report was prepared as an account of work sponsored by the United States Government. Neither the United States nor the United States Department of Energy, nor any of their employees, nor any of their contractors, subcontractors, or their employees, makes any warranty, express or implied, or assumes any legal liability or responsibility for the accuracy, completeness or usefuiness of any information, apparatus, product or process disclosed, or represents that its use would not infringe privately owned rights.
\end{abstract}


AQUATIC BIOMASS AS A SOURCE OF FUELS AND CHEMICALS

\author{
LAWRENCE P. RAYMOND, Ph.D.
} Manager, Biomass Programs

Solar Energy Research Institute

1617 Cole Boulevard

Golden, Colorado

U.S.A. 80401

\begin{abstract}
The Aquatic Species Program (ASP) addresses the development of technologies that produce and utilize plant biomass species which naturally inhabit wetlands or submerged areas. Processes being developed through this program take advantage of the rapid growth rates, high yields, and extraordinary chemical compositions inherently associated with aquatic species. Emphasis is placed on salt tolerant species for cultivation on poorly utilized, low-value lands, where conventional agriculture is not economic. Candidate species are identified from 1) microalgre unicellular plants that are natural factories for converting sunlight into high quality oils; 2) macroaigae - iarge, chemicaliy unique plants that can be easily fermented to methane gas or alcohols; and 3 ) emergents - plants that grow rooted in waterways and bogs, but are partially exposed above water.
\end{abstract}

Within the next five years, the conditions and resources necessary for sustained systems operations are to be defined, design parameters examined, and experimental facilities developed. Succeeding years are planned to focus on resolving major technical hurdles in systems operations, integration, and component performance.

This paper updates the technical progress in this program, describes severat aspects of evolving systems concepts, and attempts to provide some perspectives based on potential economics.

\title{
INTRODUCTION
}

Biological organisms have had millions of years to evolve and improve the apparatus and mechanisms for transforming sunlight into chemical energy. One result of this progression is that numerous plants now exist that are capable of producing a wide variety of chemicals. albeit correspondingly coupled with a wide variety of eificiencies. At this moment in time, plant species can be found that. in aggregate, can yield virtually every orzanic compound utilized by industry.

This broad capability of chemicals production is no where better represented than by aquatic plants, i.e. plants that in nature occuoy wetland or fully submerged habitats. Aquatic plants are noted for their high levels of productivity and photosynthetic efficiencies, as well as the extrgordinary range of chemicals they produce. For example, resear con conducted at, or through the sponsorship of SERI has shown that microalgae are capable of producing a variety of oil compounds, including hydrocarbons and mono-, di-, and triglycerides having fatty acid moieties ranging irom $C_{10}$ to $C_{38}$ in chain length, in saturated or unsaturated forms, syclic, branched, or straight chain, attacining of devoid of linkages with oxygen, with these characteristics dependent upon species and/or culture conditions. Other aquatic microorganisms like the archaebacteria synthesize di- and tetra ethers of various polyols like glycerol; photosynthetic bacteria like Rhodomonas produce hydrogen directly while decomposing organic substrates, and acetogenic bacteria effectively degrade comolex urganics to simple chemicals such as acetate, formate, and propionate. Larger aquatic plants, such as seaveeds, water hvacinth, bulrusies and cattails, are excellent sources of carbohydrates and specialty derivitives such as agars, alginates. thickening agents and tibers.

Aquatic plants are credited with extraordinary productivity capabilities. Sheler and Soeder (1980) note that $55-95$ tons $\mathrm{ha}^{-1} \mathrm{yr}^{-1}$ are within the productivity range eommonly observed for microgigal spesies. Andrews and Pratt (1979) :eported $\pm 0 \mathrm{dry}$ tons $\mathrm{ag}^{-1} \mathrm{yr}^{-1}$ for catiails having oniy a 5 month growing season. Neushul, et al. (1931) recently demonstrated productivities as high as 66 dry tons ha $\mathrm{yt}^{-1}$ ior the giant kelp ifacrocysis pyrifera. Similarly, Ryther (1982) reported year cound sustained production at 82 tons per ha"ty for 
Gracillaria. These compare with $20-50$ dry tons $\mathrm{ha}^{-1} \mathrm{yr}^{-1}$ for some of the most productive terresterial crops known, corn and sugar cane (Kresovich, et al. 1981).

A further characteristic that lends to the attractiveness of aquatic plants is their capacity to proliferate in areas and under conditions not suitable for growing conventional agriculture crops. Many species tolerate, in fact require, waters having salinities in excess of what can be used for conventional farming. This is an all too well recognized fact in the western and central United States where every milligram increase in irrigation water salinity above $700 \mathrm{pgm}$, causes the value of regional American agriculture to decrease by $\$ 472,000$ annually. Halophilic aquatic plants are capable of reversing this trend by making beneficial use of saline waters. Species of microalgae exist that grow well in waters approaching salt saturation (between 4 and 5 molar salt), while simultaneously providing an output of protein, glycerol, and $\beta$-carotene (Ben-Amotz and Avron, 1980).

Large regional expanses, such as the American Southwestern Deserts, which have few population or industrial centers, little potable water, and hot arid climates, are ideal for aquatic plant production since land is readily available, inexpensive, and comparstively unproductive. Further, water limitations do not exist orovided saline water can be used, such as in microalgal production. Figure 1 shows the major regions within the continental U.S.A. where significant reservoirs of saline ground water have been located. Figure 2 reducess and restricts this area to the arid Southwest, where average daily insolation equals or exceeds $450 \mathrm{cal} \mathrm{cm}^{-2}$ day $^{-1}$. Under this condition, the horizontal land area overlying saline reservoirs approaches 36 million hectares for which there is little competing present use, but which might be suitable for halophilic aquatic biomass production.

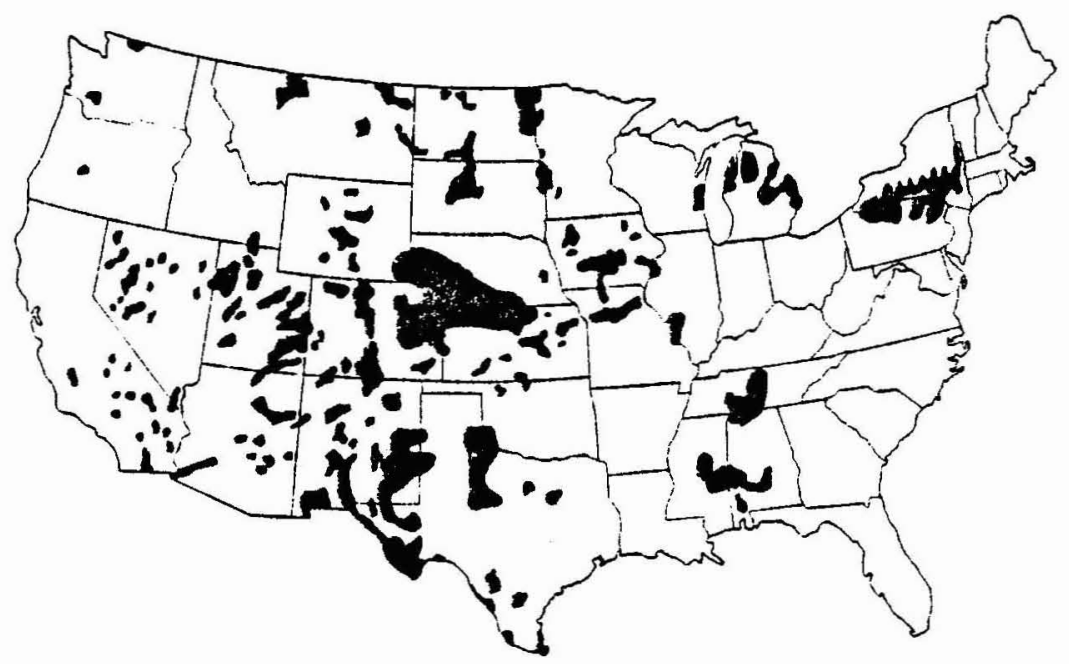

Eig. 1. Shallow saline ground water reservoirs (salinity $\simeq 3,000$ ppm) based on USGS :eport HA-199, 1965 .

Thus, aquatic biomass appear to have significant potential for impacting and contributing to the fuels and chemicals markets on the basis of chemical composition, productivity, compatibility with available resources and lack of competition for water, land, and sunlight. With these advantageous, it is reasonable to question why industry has not responded to this technical challenge. The ansiver is based upon technical, logistic, and economic questions of significant proportion, sufficient to place development isks well beyond the capacity of the private sector to accept. It is towards providing these answers as well as practical solutions to technical hurdles that the SERI/Department of Energy Aquatic Species Program is directed.

\section{The Aquatic Soecies Program}

The Aquatic Soecies Program is guided by one overriding technical objective-to develop technologies that utilize aquatic plants for producing petroleum replacement products. The realization of this objective uitimately requires that biomass energy development be based upon the areation of systerrs, the external boundaries of which lie outsice both biomass production and the orocessing of products in volumes responsive to market demands. Once conceptual systems are cescribed, the RSD needs can be more specifically defined and evaluated with respect to their importance in achieving technical success. given the usual constraints of time and budget.

Figure 3 shows a conceptual sustem that might be considered applicable to aquatic plants in general, but which is specifically directed to the microalgae. EAch major system component-production, harvesting, processing and conversion-is showr along with interdependencies in an overall scheme :or converting suniight into fuels, petrochemicals, feeds and specialties. Various R\&D opoortunities are identified which may lead to reductions in capital investment requirements and, or operating costs while concurrentiv inoroving efticienc:. 


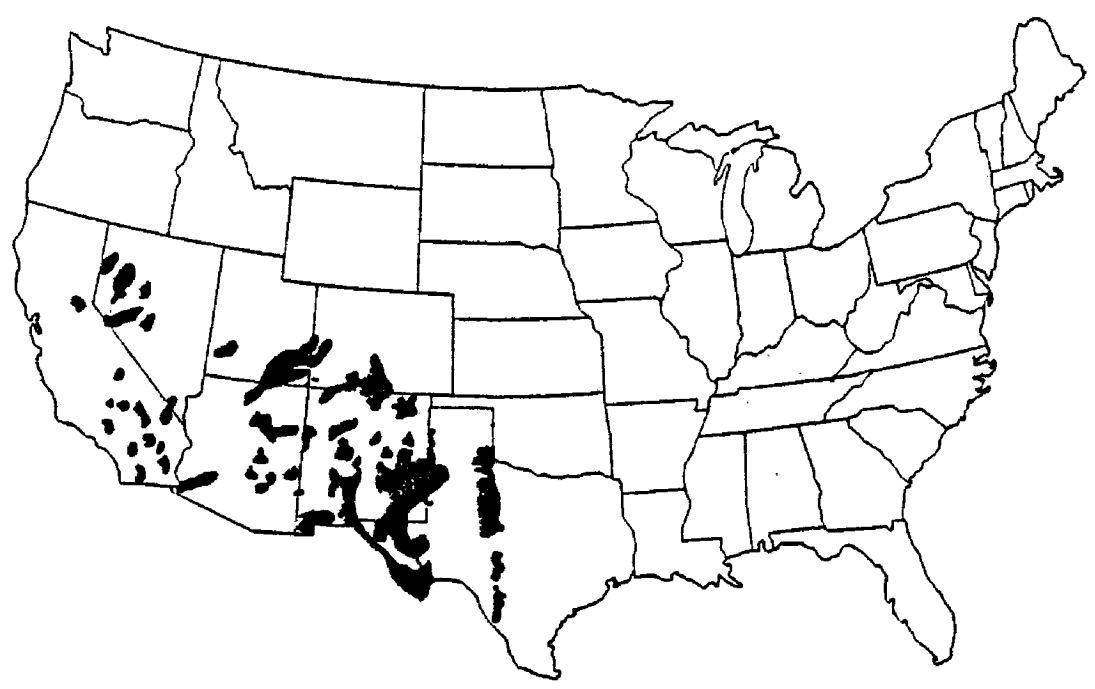

Fig. 2. Locations of saline ground water reservoirs are illustrated for the American southwest. 36 million hectares of land overlays these subterranean deposits, and potentially could be deployed for production of halophilic plants.

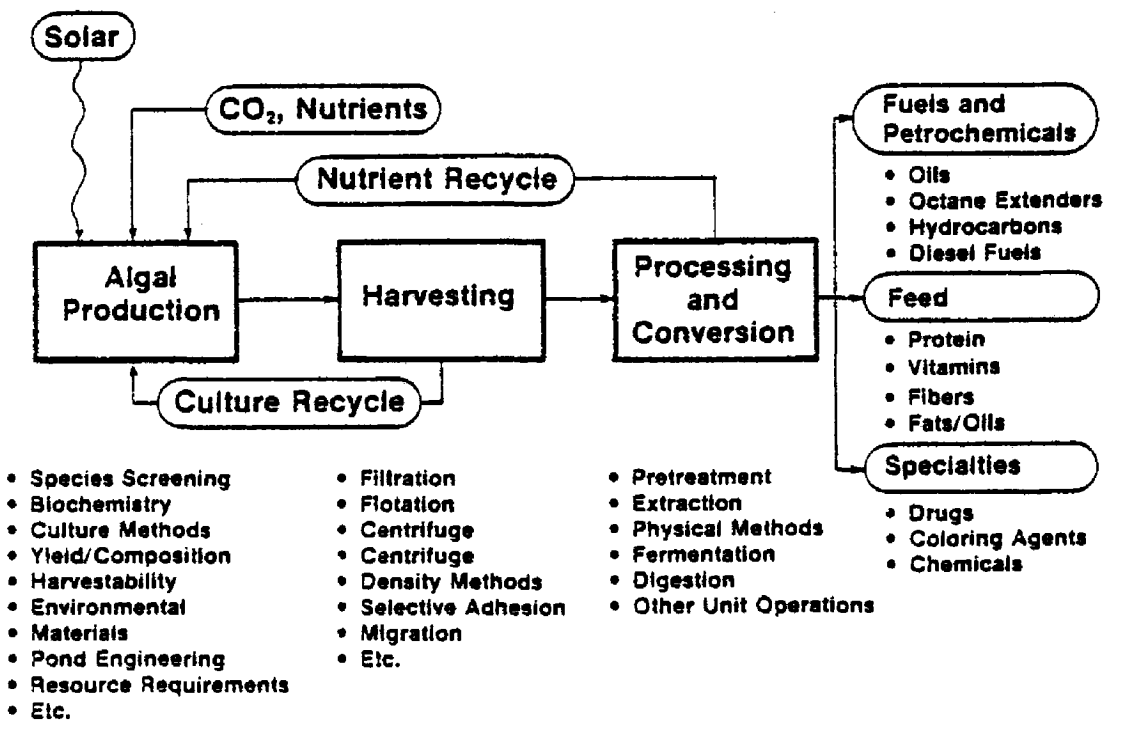

Fig. 3. A typical aquatic biomass energy system is illustrated, but emphasis is placed on microalgae.

This concept :vas modified recently with the objective to identify that set of R\&D opportunities with the greatest combined potential for success and technology improvement for the research dollar. This is shown as Fig. 4. In this case, orovisions for economies of scale, market size, supply, and demand conditions were included to allow the system to respond to its environment, rather than be independent of real worid constraints. Soecific cost data were gathered and employed when available; otherwise cost estimates were prepared utilizing a standard list of assumptions. These data were then varied over a range considered representative of the potential for technology improvement. both from a pessimistic and an optimistic view. This analysis indicated that improvements in jiomass yield and reductions in capital investment costs were the two most important jeneral parameters to address for the purpose of expanding the ability of ricroalga! products to coinpete on the opened narket. 


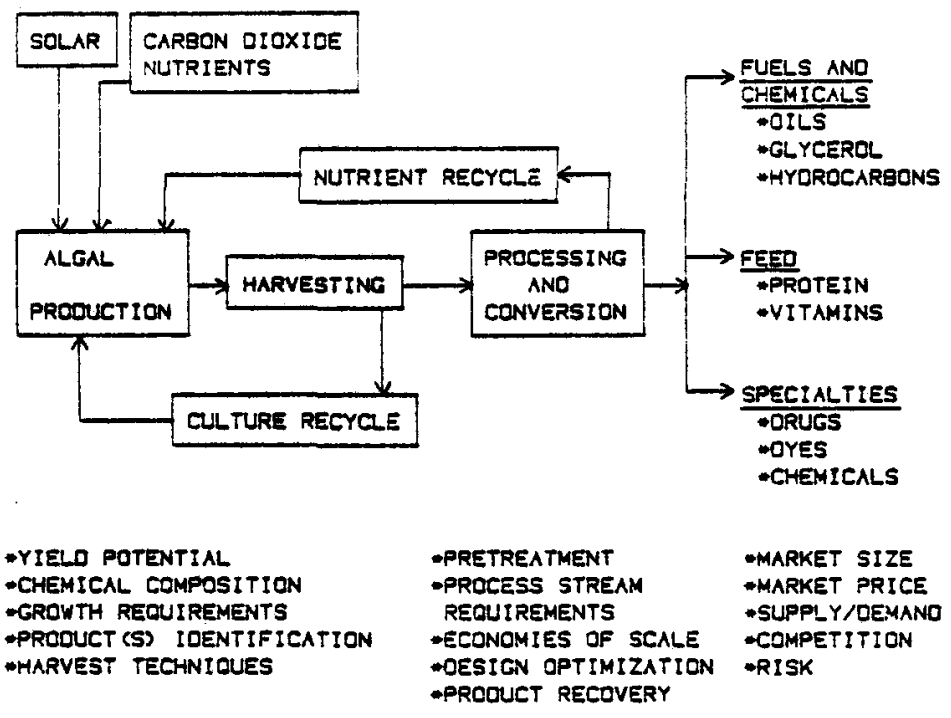

Fig. 4. Overview of microalgae production systems as seen from an economic perspective. This places the system in a real world context.

This analysis was extended to establish performance goals for research seeking to improve yield and capital investment. Historical and theoretical data were assembled to bound achievable yield and capital requirements. These limits were $23-168$ dry tons $\mathrm{ha}^{-1} \mathrm{yr}^{-1}$ (corresponding to easily realizable production utilizing present technology and optimistically attainable; respectively) and $\$ 5.30-\$ 32.20 \mathrm{~m}^{-2}$ capital investment. Constraints due to operating costs, processing costs, and retum on equity requirements, indicated that vields approaching 85 dry tons ha $\mathrm{yr}^{-1}$ were required simply to breakeven in a $\$ 500$ per ton market. Since $\$ 500$ per ton ${ }^{-1}$ is near the value for large volume chemical markets, and 85 dry ton ha $a^{-1} \mathrm{yr}^{-1}$ yields is near the upper limit of state of the art productivity, yields must be improved before microalgal oroducts can enter the chemicals market.

Even maximal yield and minimal capital investment do not permit entry into the fuels market. The reason is simply that operating and processing cost requirements are higher than the present market price of fuels in the United States. This observation leads to at least two possible conclusions, that microalgal systems may never impact the fuels market, or that multiple products of differing value must be derived from microalgal systems so that the average revenue obtained per dry ton of algae approaches $\$ 300$.

The quantitative result of this analysis was the pre|iminary base from which an initial set of performance goals could be drawn. Yields approaching 135 tons $\mathrm{ha}^{-1} \mathrm{yr}^{-1}$ and ootained from facilities having capital costs less than $\$ 10 \mathrm{~m}^{-2}$ are targets for $R \& D$ to strive for if microalgae are to meet the program objective.

This attempt to obtain preliminary assessments of microalgae production indicates that low capital costs and high yields of algae may be required to penetrate the bulk fuels and chemical markat. Other process improvements may help to reduce the need for the low capital cost and high vield. While it is expected that data refinements will help identify other improvement requirements and provide more realistic cost estimates, a reasonable basis has been provided for specifying objectives ior this program area. These are:

- Develop microaigal energy systems that yield multipie products.

- Reduce the costs associated with maintaining high productivity.

- Define the design parameters required to sustain productivity at the 135 dry tons per hectare level.

These broad objectives are sought through carefully coordinated and focused $R \& D$ in the following four areas:

1) Selection of species to provide maximum yields of biomass of cesired compositions. Species are seiected according to data comparing growth rates, light requirements (both intensity and wavelength responses), :emperature tolerance, nutrient demands, salinity and pH limitations, as vell as chemical composition, which may be controlled through the manipulation of the chemical and pinsical culture environment.

2) Definition of cultivation and resource requirements. This entaiis defining the contributions of production system desizn parameters to productivity, as vell as iCentifying and matching the physical and chemical resources required for sustained operations.

3) Development of processing technology. This involves harvesting. fractionation, and conversion of biomass into fuels and high-energy chemicals.

4) Systems integrations. This requires the de tinition and joining of ecmponents required tor fully functional, practical systems. 


\section{Program Status}

Research conducted at, or through the sponsorship of SERI/DOE has concentrated on these four main areas. When this research began, the state of the art focused on producing meso or thermophilic green and bluegreen microalgae with a primary view on world protein production. While aspects of productivity and protein content typical of vegetative and expontentially growing microalgae provided inputs to this effort, concerns were not openly expressed regarding high nucleic acid concentrations and incomplete amino acid profiles of widely cuitivated species like Chlorella and Scenedesmus. Spirulina, however, could be regarded as an exception, having a documented protein value approaching egg-yolk (Durand-Chastel, 1980).

Regardless of intended end-use, no fully autotrophic outdoor production system had achieved the productivity levels estimated to be required for entry into the markets to be addressed by the SERI/DOE Aquatics Species Program (see Table 1). Clearly, advances had to be made in cultivation technology; the list of suitable species needed to be expanded, and techniques had to be identified for maintaining desired chemical composition. Considerable advances can now be reported in all areas.

TABLE 1 Yield Performance Standards for Microalgae Production in 1979

\begin{tabular}{|c|c|c|c|}
\hline Location & Species & $\begin{array}{l}\text { Productivity } \\
\text { Metric Tons } \mathrm{Ha}^{-1} \mathrm{Yr}^{-1}\end{array}$ & Reference \\
\hline South Africa & Chlorella sp. & 68.5 & $\begin{array}{l}\text { Toerien and } \\
\text { Grobbelaar, } 1980\end{array}$ \\
\hline Taiwan & $\begin{array}{l}\text { Chlorella ellipsoidea } \\
\text { Chlorella } \\
\text { Ovrenoidosa }\end{array}$ & $\begin{array}{c}109.6 \\
\text { (mixotrophic) }\end{array}$ & Kawaguchi, 1980 \\
\hline Inơia & Scenedesmus acutus & $73-91$ & $\begin{array}{l}\text { Becker and } \\
\text { Venkataraman, } 1980\end{array}$ \\
\hline Mexico & Spirulina maxima & 36.5 & $\begin{array}{l}\text { Durand-Chastel and } \\
\text { Clement, 1975 } \\
\text { Durand-Chastel, } 1980\end{array}$ \\
\hline Israel & Spirulina olatensis & $60-80$ & Richmond, et al. 1980 \\
\hline Tha iland & Scenedesmus acutus & 55 & Sinchumpasak, 1980 \\
\hline
\end{tabular}

\section{1) Soecies Selection}

Microalgal species are collected, cultured, and screened for oil production using a SERI developed rapid screening technique. Three new oil producing species have been identified, two Chlorelia strains and a Scenedesmus, the latter containing hydrogenase in addition. The goal for FY 83 is to develop a resource pool of 80 species. Experiments have been initiated to explore the biosynthetic regulation and control mechanisms affecting lipid production in macroalgae.

Under subcontract with SERI, the University of Califomia, San Diego has been characterizing marine phytoplankton responses during period of nitrogen sufficiency and nitrogen starvation (Thomas, 1982). Using dense thin cultures, various aigal species have been screened for their lipid, protein, and carbohydrate content. Both nitrogen defijciency and light intensity effects have been assessed. The highest yield ( $21.5 \mathrm{gm}$ try weight $\mathrm{m}^{-2} \mathrm{day}^{-1}$ ) and efficiency (i2.2\%) was obtained with Phaeodactylum $2 t$ a light intensity equaling $39 \%$ of naximum sunlight at La, Jolla, California and $\mathrm{N}$ sufficiency. Lipid and protein yields were 5.62 and $13.0 \mathrm{gm}$ dry weight $\mathrm{m}^{-2} \mathrm{dgy}^{-1}$, respectively. Dry weight, lipid, and protein yields translate to $58.3,17.7$, and 40.9 metric tons ha $-\mathrm{yr}$. Comparative higher plant yields average 7.3 $\mathrm{gm}$ try weight $\mathrm{m}^{-2} \mathrm{day}^{-1}$. Increased light intensity or cell density did not increase vields or efficiencies. Nitrogen limitation ingreases phaeodactylurn lipid content from $20 \%$ to $30 \%$ of the dry weight, but lipid vield is reduced (to $2.39 \mathrm{gm} \mathrm{m}^{-2}$ day ${ }^{-1}$ ) jecause of low overall dry weight yield. No other species (Dunaliella, MonaLlantus, Tetraselmis, Isochrvsis or Botrvococcus) gave as high yields (dry weight, lipid or protein) or efficiency as Phaeodactvlum. Nitrogen deficiency did not increase lipid content in any of these other species and, in Dunaliella and Tetraselmis, carbohydrate, rather than lipid, levels were greatly increased by deticiency. Table 2 provides comparative data on the yieids and efficiencies for these species.

\section{2) Culture and Resource Requirements}

Under subcontract with the University of Hawaii, a $50 \mathrm{~m}^{2}$ outdoor (Laws, 1982) experimental algal כroduction outdoor raceway (APQ) has been designed, constructed, and tested. Nutrient, temperature and lighting requirements were established through laboratory experiments, using Phaeodactvlum tricornutum as iest species. The APR has been operated, achieving cell densities up to +2 million per millimeter, at specific growth rates of 0.35 to 0.45 per day. Chemical somposition is $25 \%$ lipid, $55 \%$ protein, and $20 \%$ carbohydrate. Photosynthetic eificiencies of approximately $15 \%$ PAR have been ojtained. Five $8 \mathrm{~m}^{2}$ raceway units have been cesigned and are currently being constructed. These units will be used to study the efiects of variations of design and performance parameters. Established values will be incorporated into the $50 \mathrm{~m}^{2}$ system which will be operated continuously ior at least six months to test sustained yield pertormance. 
TABLE 2 Yields and Photosynthetic Efficiencies of Several Microalgae at Moderate Light Intensities and Nutrient Sufficiency

\begin{tabular}{|c|c|c|c|c|}
\hline Alga & $\begin{array}{l}\text { Yield (gm } \\
\text { dry } w t . m-2 \\
\text { day }-1 \text { ) }\end{array}$ & $\begin{array}{l}\text { PAR* } \\
\text { Efficiency } \\
\text { (\%) }\end{array}$ & $\begin{array}{l}\text { Lipid yield } \\
\text { (gm m-2 } \\
\text { day }^{-1} \text { ) }\end{array}$ & $\begin{array}{l}\text { Protein yield } \\
\left(\operatorname{gm~m}^{-2}\right. \\
\left.\text { day }^{-1}\right)\end{array}$ \\
\hline $\begin{array}{l}\text { Phaeodactvlum } \\
\text { (Batch culture) } \\
\text { (Continuous culture) }\end{array}$ & $\begin{array}{l}21.7 \\
16.2\end{array}$ & $\begin{array}{r}12.2 \\
6.2\end{array}$ & $\begin{array}{l}5.62 \\
3.22\end{array}$ & $\begin{array}{r}13.0 \\
9.5\end{array}$ \\
\hline $\begin{array}{l}\frac{\text { Dunaliella }}{\text { (Batch culture) }} \\
\text { (Continuous culture) }\end{array}$ & $\begin{array}{r}8.7 \\
12.0\end{array}$ & $\begin{array}{l}3.5 \\
3.8\end{array}$ & $\overline{2.59}$ & $\overrightarrow{8.4}$ \\
\hline$\frac{\text { Monallatus }}{\text { (Batch culture) }}$ & 7.1 & 4.0 & 1.42 & 2.8 \\
\hline$\frac{\text { Tetraselmis }}{\text { (Batch \& cont. cult.) }}$ & 1.3 & 7.6 & 4.48 & - \\
\hline$\frac{\text { Isochrysis }}{\text { (Batch culture) }}$ & 6.7 & 2.8 & 1.77 & - \\
\hline$\frac{\text { Botryococeus }}{\text { (Batch culture) }}$ & 4.0 & 1.7 & 1.20 & - \\
\hline
\end{tabular}

*PAR = Photosynthetically active radiation, or light energy between wavelengths of 400 and $700 \mathrm{~mm}$.

Performance projections based on current data were presented by Laws (1982) as follows:

- The optimum efficiency of solar energy conversion in the system will probably be about $10 \%$.

- The optimum obtainable yield will probably be about $40-50 \mathrm{~g}$ dry weight $\mathrm{m}^{-2}$ day $^{-1}$.

- The optimum lipid and grotein production rates from $\underline{P}$ tricornutum will probably be about $3-10 \mathrm{~g}$ $\mathrm{m}^{-2} \mathrm{day}^{-1}$ and $16-20 \mathrm{~g} \mathrm{~m}^{-2} \mathrm{day}^{-1}$ respectively.

- The energy yield from the system could be as much as $250-300 \mathrm{kcal} \mathrm{m} \mathrm{m}^{-2} \mathrm{day}^{-1}$ if the entire product were combusted. The energy yieid from the lipid would be about $70-90 \mathrm{kcal} \mathrm{m}{ }^{-2} \mathrm{day}^{-1}$, equivalent to $170-220$ bol ha $\mathrm{hr}^{-1}$ of crude oil.

3) Processing Technology

A subcontract is in force with the Georgia Institute of Technology to perform chemical analyses of microalgae, conduct studies of the effects of cultivation conditions on chemical composition, and identify and evaluate process techniques for lipid extraction and recovery. Tornabene (1982) recently provided $a$ detailed analysis of the halophilic microalga Neochlorisis oleoabundans cultivated in mineral medium deficient in nitrogen. The yield of oily lipids ivas 35-45\% of cell dry weight. Triglycerides comprised $80 \%$ of the total lipids. Aliphatic hydrocerbons, sterols, pigments, glycolipids and phospholipids comprised the remaining lipid fraction. Saturated, monunsaturated and diunsaturated octadecanoic acid represented approximately one-half of the total fatty acids. Detailed characteristics are provided in Tables 3 and 4 .

\section{Directions of Fut're Research and Develooment}

The long-range goal of the Aquatic Species Program is to identify and to research innovative biomass energy systems that have significant potential for meeting continued national requirements for fuels and chemicals. Recognizing the high risks associated with the development of such ootions, the program has elected to pursue a dynamic strategy that can respond to projected fluctuations in product supplies, market demands. national needs, and new technical developments. Close associations and coordinated activities are established and maintained with industry, other research organizations, and governmental agencies to obtain the information needed to guice research and to encourage timely trarsfer of research results.

Analyses performed to date have indicated substantial advantages to jiomass energy systems conceived to operate in underutilized areas, such as arid lands, marginal lands, and wetlands, to utilize saline or otherwise nonootable waters, and to have beneficial impacts on environmental resources. These factors eliminate or minimize land-use conflicts, competition for water, and dificulties in environmental degradation that could adversely influence the long-term operations of the systems. The program area is carefully focused to incorporate these factors, and make major improvements in the procuction and conversion of aquatic biomass in to useful fuels and chemicals.

Major decisions will need to je made as requirements are oetter cefined for technical developments and sustained systems operations. In order for aquatic species, particulariy microalgae. to oroduce oils, certain physical and chemical requirements must je met, including land, water, salts, nutrients. carbon dioxide, and sunlight. While it aopears this can be achieved using arid lands that overlay shallow saline jroundwater 
reservoirs, field studies must be conducted to verify this potential. Algal species, capable of growing and producing oils from these water supplies, need to be identified, characterized for product potentials, and selected. Appropriate systems must be technically feasible for algal mass culture. Each of these research areas is essential to the success of the program and will constitute major determining factors over the next five years.

TABLE 3 Characteristics of Neutral Lipid Components of N. Oleoabundans (From Tornabene, 1982)

\begin{tabular}{|c|c|c|c|c|c|c|}
\hline \multirow[b]{2}{*}{ Av. $R_{f}$ Values } & \multicolumn{5}{|c|}{ Eluetes From Silic Acid Column } & \multirow{2}{*}{$\begin{array}{c}\text { Probable } \\
\text { Identification } \\
\text { of Compounds }\end{array}$} \\
\hline & Hexane & Benzene & $\mathrm{CHCl}_{3}$ & Acetone & $\mathrm{MeOH}$ & \\
\hline 0.88 & 0.7 & - & - & - & - & Hydrocarbons \\
\hline 0.79 & - & 1.2 & - & - & - & Steryl esters \\
\hline 0.69 & - & 0.2 & 0.1 & - & - & Methy esters \\
\hline 0.39 & - & - & 73.5 & 7.1 & - & Triglycerides \\
\hline 0.50 & - & 0.2 & 0.1 & 0.3 & 0.1 & Pigment \\
\hline 0.48 & - & 0.3 & 0.1 & 0.4 & 0.1 & Pigment \\
\hline 0.47 & - & 0.2 & 0.1 & 0.4 & 0.1 & Pigment \\
\hline 0.46 & - & 0.6 & - & - & - & Pigment \\
\hline 0.46 & - & - & 0.7 & - & - & 1,3 diglyceride \\
\hline 0.42 & - & 0.5 & - & - & - & Pigment \\
\hline 0.42 & - & - & 0.1 & - & - & 1,2 diglyceride \\
\hline 0.39 & - & 0.7 & 0.5 & - & - & $\begin{array}{l}\text { Free fatty acids } \\
\text { and free sterols }\end{array}$ \\
\hline 0.39 & - & - & - & 1.1 & - & Pigment \\
\hline 0.30 & - & - & - & 1.1 & - & Pigment \\
\hline 0.25 & - & - & - & 0.1 & - & Pigment \\
\hline 0.18 & - & - & 0.1 & - & - & Monoglyceride \\
\hline 0.00 & - & - & - & 1.3 & 8.0 & Polar lipids \\
\hline
\end{tabular}

Data obtained from TLC developed with neutral lipid solvent $A, R_{f}$ values for authentic lipids were found to be eicosane, 0.88 ; cholesteryl oleate, 0.79 ; methyl stearate, 0.69 ; Tripalmitin, $0.5 ; 1,3-$ dipalmitin, $0.45 ; 1,2$ dipalmitin, 0.41 ; myristic acid 0.39 ; monopalmitin, 0.17 . Values, expressed as percentage of the total lipids were determined ' ith a recording Zeineh soft laser scanning densitometer.

TABLE 4 Fatty Acid Methyl Esters of Triglvcerides of $\mathrm{N}$. oleoabundans (from Tornaberie. 1982)

\begin{tabular}{ccccc}
\hline Peak $\#$ & $\begin{array}{c}\text { Fatty Acid } \\
\text { Identity }\end{array}$ & Molec. Wt. & Area 8 & $\begin{array}{c}\text { Position of } \\
\text { Double Band }\end{array}$ \\
\hline 1 & $14: 1$ & 240 & 0.4 & \\
2 & $14: 0$ & 242 & 1.6 & \\
3 & iso-15:0 & 256 & 1.0 & \\
4 & $15: 0$ & 256 & 0.4 & \\
5 & $16: 2$ & 266 & 2.5 & 7 \\
0 & $16: 1$ & 268 & 3.5 & \\
7 & $15: 0$ & 270 & 15.0 & \\
3 & so-17:0 & 284 & 8.4 & \\
9 & C17:1 & 282 & 1.0 & \\
10 & $17: 0$ & 284 & 3.3 & \\
11 & $18: 2$ & 294 & 7.4 & \\
12 & $18: 1$ & 296 & 36.0 & \\
13 & $18: 0$ & 298 & 11.0 & \\
14 & iso-19:0 & 312 & 0.3 & \\
15 & $19: 1$ & 310 & 0.1 & \\
16 & $19: 0$ & 312 & 0.3 & \\
17 & $20: 1$ & 32. & 2.5 & \\
13 & $20: 0$ & 326 & 2.1 & \\
\hline
\end{tabular}




\section{REFERENCES}

Andrews, N. J. and D. G. Pratt. 1978. The potential of cattails (Typha spp.) as an Energy Source: Productivity in Maneged Stands. J. Minn. Acad. Se. 44: 5-8.

Becker, E. W. and L. V. Venkataraman. 1980. Production and processing of algae in pilot plant scale experiences of the Indo-German project. IN: Shelef, G. and C. J. Soeder, Eds., Algae Biomass: Production and Use. Elsevier/North-Holland Biomedical Press, Amsterdam, New York, Oxford.

Ben-Amotz, A. and M. Avron. 1980. Glyceral, $\beta$-Carotene, and dry algal meal production by commercial cultiation of Danaliella. In. Shelef, G. and C. J. Soeder, Eds., Algae Biomass: Production and Use. Elsevier/North-Folland Biomedical Press, Amsterdam, New York, Oxford.

Durand-Chastel, H. 1980. Production and use of Spirulina in Mexico. In: Shelef, G. and C. J. Soeder, Eds. Algae Biomass: Production and Use. Elsevier/North-Holland Biomedical Press, Amsterdam, New York, Oxford.

Durand-Chastel, H. and G. Glement. 1975. L'Algae Spiruline, Aliment de Demain. 9th internat. Congress on Nutrition, Sept. 1972, I.F.P. Report No. 20,743.

Kawaguchi, K. 1980. Microalgae Production Systems in Asia. In. Shelef. G., and C. J. Soeder, Eds, Algre Biomass: Production and Use. Elsevier/North-Holland Biomedical Press, Amsterdam, New York, Oxford.

Kresovich, S., Ck. K. Wagner, D. A. Scantland, and W. T. Lawhom. 1981. Emergent aquatic plants: Biological and Economic perspectives. Biomass, $1,127-144$.

Laws, E. 1982. Results from preliminary studies on the use of flashing light to enhance algal mass culture production. Proceedings of SERI Investiggtor's conference. June, 1982 SERI Technical Report.

Neushal, M., B.W.W. Harger, and J.W. Woessner. 1981. Laborgtory and nearshort filed studies of the giant California kelp as an energy crop plant. Proc. Intl. Gas Research Conference, Los Angeles. 1981.

Richmond, A., A. Vonshak and S. (Malis) Arad. 1980. Environmental limitation in outdoor production of algal biomass. In: Shelef, G., and C. J. Soeder, Eds., Algae Biomass: Production and Use. Elsevier/NorthHolland Biomedical Press, Amsterdam, New York, Oxford.

Ryther, J. H., T. A. DeBusk, D. A. Andrews, C. Habig, L. P. LaBaff, L. D. Williams, and B. E. Fallener. 1982. Cultivation of macroscopic marine algae. Proceedings of SERI Investigator's Conference. June, 1982. SERI Technical Report.

Thomas, W. H. 1982. Laboratory selection of microalgae for maximum lipid and protein production. Proceedings of SERI investigator's conference. June, 1982. SERI technical report.

Toerien, D. F. and J. U. Grobbelagr. 1980. Algal mass cultivation experiments in South Africa. In: Shelef, G. and C.J. Soeder. Algae Biomass: Production and Use. Elsevier/North-Holland Biomedical Press, Amsterdam, New York, Oxford.

Tornabene, T. G. 1982. Chemical profiles of microalgae, with emphasis on lipids. Proceedings of SERI Investigator's Conference. June, 1982. SE RI Technical Report.

Shelê,, G. and C. J. Soeder. 1980. Algae Biomass: Production and Use. Elsevier/North-Holland Biomedical Press. Amsterdam, New York, Oxford. 852 pp.

Sirchumpasak, O. 1980. Microalgal biomass production in Tailand. In. Shelf, G. and C. J. Soeder, Eds. Algae Siomass: Production and Use. Elsevier/North-Holland Biomedical Press. Amsterdam, New York, Oxiord. 